\title{
Barriers to inter-organisational collaboration amongst performing arts organisations in South Africa
}

\author{
Marise Mishan ${ }^{\mathrm{a} *}$ and Anthony Prangley ${ }^{\mathrm{b}}$ \\ ${ }^{a}$ Performing Artist, Choreographer, MBA Graduate from the Gordon Institute of Business Science, \\ University of Pretoria, Johannesburg, South Africa; ${ }^{b}$ Gordon Institute of Business Science, \\ University of Pretoria, Johannesburg, South Africa
}

There is significant financial pressure on the performing arts sector in South Africa. Demand for the performing arts sector needs to grow if this is to change. This requires inter-organisational collaboration. This study explores, through a grounded qualitative approach, the barriers to interorganisational collaboration amongst performing arts organisations (PAOs) in South Africa, as seen through the experience of strategic leaders in the sector. These included views from commercial producers, theatres, festival and independent companies, and performing arts promoters. These organisations were professionally run with paid staff. The findings are then compared with the emerging literature in the field, conclusions drawn and recommendations made. Barriers identified include personal pride, artistic ideology, the survivalist reality, fragmented audiences and lack of support from government. The contextual complex-ity of South African post-apartheid society also acts as a barrier to collaboration. Ideas from the literature for overcoming these barriers are included. For practitioners, the problem of inter-organisational collaboration in the performing arts was identified. It appears as if inter-organisational collaboration (as a means of stimulating primary demand) is constrained when the financial pressures on a sector are so great as to push organisations into a corner. For academics, this study makes a contribution to the literature that is part of a broader relational and 'shared-power' turn in leadership studies, where collective action is increasingly required. The strong importance of contextual barriers confirms the call for an increased 'field-level' analysis.

Keywords: arts collaboration; South African performing arts sector; inter-organisational collaboration

\section{Introduction}

The combined effect of increasing competition from other sectors, decreasing government funding and an apathetic audience has led to a shrinking performing arts market in South Africa (d'Astous, Colbert and Fournier 2007, Joffe and Newton 2008). This is creating significant financial pressure amongst performing arts organisations (PAOs). If things continue as they are, some organisations will not exist in a few years' time.

These unfavourable industry trends and PAOs' seeming inability to attract new or sufficient customers indicate a need for PAOs to assume more financial control of the performing arts industry to ensure their own sustainability (Boorsma and Chiaravalloti 2010, Thomas et al. 2009).

*Corresponding author. Email: marisedusheiko@gmail.com 
How can this be done? A PAO's continual focus on marketing just one's own art form is insufficient as existing ticket sales cover only one third of production costs (BASA 2009). Demand for the performing arts sector needs to grow if this is to change. PAOs need to stimulate primary demand, which will increase the size of the total market. Simply put, they need to increase the size of the pie. Kotler and Scheff (1997) and Colbert (2009) argue that urgency in the sector can create the impetus and the opportunity to do this. Kotler and Scheff (1997) advocate inter-organisational collaboration as a key method of primary demand stimulation. Others agree and suggest that a shrinking market calls for strategic alliances and collaboration (Ricco 2009).

Inter-organisational collaboration has received significant scholarly attention in the last few years (Huxham and Vangen 2000, Connelly 2007). This has occurred within the public sector (Morse 2010), the non-profit sector (Guo and Acar 2005, Ospina and Foldy 2010) and the private sector (Müller-Seitz 2012). Research has also explored cross-sector collaboration (Crosby and Bryson 2005).

One of the ways in which PAO's can grow the market is through collaboration. The process of arts production is on one level implicitly collaborative, but on another level unique and personal. The literature on inter-organisational collaboration does not adequately cover these particular dynamics and the barriers for collaboration involved.

This study explores, through a grounded qualitative approach, the barriers to interorganisational collaboration amongst PAOs in South Africa, as seen through the experience of strategic leaders in the sector. The classification of PAOs (Joffe and Newton 2008) was used in determining the range of entities to be included. These include commercial producers, theatres, festivals and independent companies. Another group, performing arts promoters, was included as they provided an outsider's perspective on inter-organisational collaboration amongst PAOs. The sample of PAOs ranged in staff sizes (including performers) from around a dozen at the low end to above 100 staff at the high end. They were professionally run, mostly not-for-profit organisations (but including some for-profit organisations) that were nonetheless under commercial pressure. They were all urban and all but two were based in Johannesburg. They were making progress in broadening the base of support to a younger audience as well as more multiracial audiences. The findings are then compared with the emerging literature in the field, and conclusions drawn and recommendations made.

Barriers identified include personal pride, artistic ideology, the survivalist reality, fragmented audiences and lack of support from government. The contextual complexity of South African post-apartheid society also acts as barrier to collaboration and this understanding of the context also exists in the minds of the audiences and many players in the sector. Ideas from the literature for overcoming these barriers are included.

The arts have a number of positive outcomes such as job creation, human development, social inclusion and cultural diversity (United Nations 2008). The growth of the performing arts sector could contribute to government's objective of creating five million jobs by 2020 (Patel 2010). Growing the arts is not only important for job creation and economic growth; the creative industries provide a platform for developing economies to generate intellectual capital, and at the same time promote social inclusion and human development (United Nations 2008).

These positive outcomes cannot be realised when the sector is under so much pressure to survive. PAOs need to stimulate the primary demand and increase the size of the pie. But there are barriers to the inter-organisational collaboration required to do this. This 
study clarifies those barriers and enhances the emerging understanding of the leadership competencies required to overcome them.

\section{Literature review}

Inter-organisational collaboration is defined for this study as the combined effort of two or more firms to create value through their combination of skills and resources (Ricco 2009). Kotler and Scheff (1997) distinguish between a normal relationship and a collaborative relationship, stating that a collaboration is a strategic alliance, more durable and pervasive than a regular relationship.

The authors divide the literature on inter-organisational collaboration into three domains. The first of these domains is the interpersonal one. This includes the nature of the individuals (often senior leaders or managers) themselves and also their relationships with one another (Connelly 2007). The second of these is the organisational domain. This includes the routine organisational pressures (for example, to raise enough funding for salaries) and dynamics of two or more organisations working together (Graf and Rothlauf 2011). The third domain refers to the socio-economic and political context or field in which the organisation operates (Müller-Seitz 2012).

The literature in this domain has a focus on issues of collaboration leadership, collaboration management and trust building. Whilst a significant body of literature on collaboration has emerged, little work has been done on the kinds of leadership required to be successful in it (Connelly 2007). Collaboration involves strategic decision-makers in organisations who are understood to have 'situated agency' (Sullivan et al. 2011). They are influenced, but not determined by structure. In terms of effective leadership in interorganisational settings, research has been conducted through a range of lenses and there is little consensus on a vocabulary or an approach. It has been referred to as: connective, distributed, intergroup, complex, collaborative, contextual, reciprocal, catalytic,

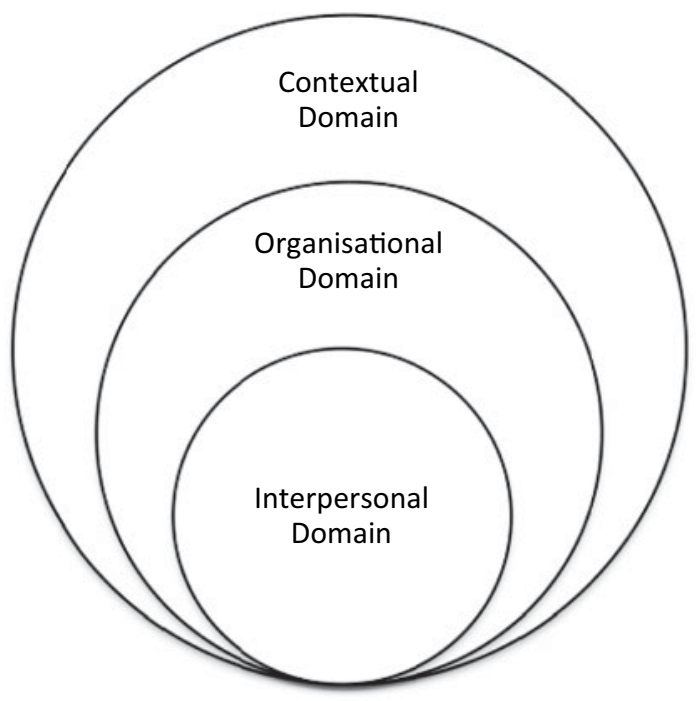

Figure 1. Three domains in inter-organisational collaboration literature. 
cosmopolitan, relational and integrative (Ospina and Foldy 2010, Sullivan et al. 2011, Hogg et al. 2012).

In terms of collaboration management, Graf and Rothlauf (2011) propose that interorganisational collaboration will not work unless there is commitment, prior experience with collaboration, trust between partners and on-going performance evaluation. Management commitment is important because an alliance requires managers to take time out of the internal operations of the PAO to manage the collaboration. Prior collaboration experience helps organisations analyse and choose the right partners to collaborate with, thereby reducing relational risk. This is a skill that takes time to develop (Das and Teng 2000).

One of the areas of consensus in the sphere of interpersonal dynamics is that trust matters. Trust in collaborations helps to create 'relational capital' (Parkhe 1993, Dyer and Singh 1998, in Graf and Rothlauf 2011). McCarthy (2006) found that trust is a key component in networks, including the networks found in the performing arts, but trust is difficult to achieve in dynamic networks because of their brief lifespan. Trust is built up gradually, through long-term commitment, further increasing collaborative effectiveness (Percy 2010). Because the performing arts industry is both a dynamic (temporary) and latent (recurring) network, the same participants will tend to meet again and again, even if only for specific, short-term projects. Therefore information on reputation can easily be spread. Trust is driven by the threat of punishment and the reward of a good reputation (Shapiro et al. 1992, in McCarthy 2006). The literature in the interpersonal domain of inter-organisational collaboration points to particular leadership and management dynamics and to the importance of trust.

From this literature, the first question that emerges is: 'When collaborating across organisations, what are the barriers in the interpersonal domain faced by PAO strategic decision-makers?'

\section{Organisational domain}

This section looks at the organisational pressures within collaboration initiatives. Positive advantages and negative disadvantages that exist are then described.

PAOs generally operate as not-for-profit enterprises (Kirchner et al. 2007). They often cannot operate on earned income or ticket sales alone and as such rely on funding from numerous parties, including the government, private sponsors, donors as well as paying audience members (Hume et al. 2007). There are significant pressures on the arts industry, particularly in South Africa, because of the financial difficulties of the performing arts sector. These difficulties partly arise because the government has shifted funding away from the arts to more pressing social issues. Interviewees expressed the view that collaboration was less likely, because with declining government support, each organisation is forced to compete for what little remains. This competitive mindset constrains collaboration. This is further entrenched by an indifferent audience, no union support and increased competition from the leisure and entertainment sector. Only a handful of ongoing mid-size to large organisations exist and collaboration between them is unlikely, given that survival is the main priority (Joffe and Newton 2008, Colbert 2009, K a n g 2010).

Advantages can accrue to the organisations involved in collaboration even as there are risks involved. Organisations need to gauge the effectiveness of the collaboration through constant performance evaluation (Graf and Rothlauf 2011). In PAOs sales, ratios and returns are not always effective indicators of success. Performance management models 
such as an amended balanced scorecard can be effective (Boorsma and Chiaravalloti 2010).

The benefits of collaboration include competitive advantage and increased innovative capacity, transfer of knowledge, shared learning and resource exchange (Jaskyte and Lee 2006). Collaboration 'facilitates the creation of new knowledge and produces synergistic solutions' (Hardy et al. 2003, p. 321).

Other advantages include increased ticket sales (Kotler and Scheff 1997), administrative expertise, fundraising and financial proficiencies, increased work opportunities for artists (Ostrower 2003), minimisation of service replication, reduced costs, expansion of professional networks, enhanced accountability pooling of funds, larger selection of artistic talent; and wider access to facilities, equipment and other components of a production (Kushner 2003). Furthermore, inter-organisational collaboration can help PAOs access a wider audience (Ostrower 2003). Kotler and Scheff (1997) also refer to cost-cutting collaborations. PAOs may be concerned about losing a patron to other art forms through joint promotions and box office collaborations, but Kotler and Scheff (1997) argue that the economies of scale PAOs achieve through these joint efforts more than offset the loss of the odd patron.

There are risks and disadvantaged to collaboration. Addressing them requires compre-hensive planning and well-designed communication channels (Kotler and Scheff 1997). Weinstein and Cook (2011) refer to alliance failure when one or more of the partners in a strategic collaboration fails to fulfil negotiated terms. Failure can include disagreement on the level of commitment to the collaboration, unmet expectations, misaligned goals (Weinstein and Cook 2011), opportunism whereby one partner tries to cheat the other so as to maximise its own profitability (Das and Teng 2000), cultural differences and clashes in management styles and operating approaches (Berger et al. 2004). In addition Ostrower (2003) cautions against partnerships that are pursued solely for grant money. Failures of these kinds result in suspicion and a breakdown of trust in the relationship, which further erodes necessary communication (Child and Faulkner 1998, Child 2003, in Weinstein and Cook 2011). The literature describes some general patterns and also describes the advantages and disadvantages for organisations when collaborating.

From this literature the second question that emerges is: 'When collaborating across organisations, what are the barriers in the organisational domain faced by PAO strategic decision-makers?'

\section{Contextual domain}

Interpersonal relationships and organisations do not exist in a vacuum; they exist within a contextual domain that, among other things, shapes the barriers to inter-organisational collaboration. Müller-Seitz (2012) calls for this increased 'field-level' analysis with a greater focus on the context of inter-organisational collaboration, because there are interdependencies between an organisation and its environment. Literature was reviewed that looks at the industry structure in South Africa; some of this literature covers perspectives that see this environment as more or less fixed, while others see it as open to being shaped by actors and organisations themselves. Collaboration requires the ability to bring diverse groups together in semi-permanent ways (Crosby and Bryson 2005). Within the context of South African PAOs, this bridging work is potentially made more complicated by the history of divisions associated with apartheid and post-apartheid South Africa. 
Collaboration often rests on relationships as well as a shared history, which is partially absent in South Africa.

There are significant related industries in the performing arts sector (Joffe and Newton 2008). These industries represent a network and often PAOs draw on the resources found in this network when staging or advertising a production (McCarthy 2006). Apart from theatre houses and a few independent companies, the majority of PAOs work toward an event, season or production within a broader organisational setting (McCarthy 2006, Joffe and Newton 2008, Sedita 2008). Because of this transient set-up, most PAOs outsource many aspects of a production, including the artists, and may not always use the same individuals and contractors.

For Cook and Hunsaker (2001) the environment is beyond the control of the organisation, specifically eco-political factors, technology, societal norms and legislation. Others argue that the boundaries that distinguish between what is within an organisation's control versus what is outside of its control are not fixed (Senge 1990a). Within this framework, individual organisations can influence their environment if they collaborate with other actors in the environment or sectors in the economy through cross-sector collaboration (Bryson et al. 2006). This requires the sharing of resources, activities and capabilities between government, business, labour, civil society, non-profit organisations, communities and the media in order to achieve large-scale outcomes that could not be achieved by single organisations (Bryson et al. 2006). The literature describes some general patterns in the structure of the industry as well as the potential to shape and be shaped by the context in which one operates.

From this final phase of literature the third question that emerges is: 'When collaborating across organisations what are the barriers in the contextual domain faced by PAO strategic decision-makers?'

In order to explore the barriers to collaboration, the literature was conceptually split into three domains, interpersonal, organisational and the contextual. These will translate into three themes that emerge from the coded data. The method of approaching this data is detailed below.

\section{Method}

\section{Research approach}

The objective of the research was to understand the barriers to inter-organisational collaboration amongst PAOs in South Africa. This is based on the need to stimulate demand for the performing arts. From the literature, three key domains were identified as interpersonal, organisational and contextual.

The study investigated the themes that emerged from in-depth qualitative interviews substantiated by a follow-up questionnaire to corroborate findings (Leedy and Ormrod 2001). The research method was qualitative, because it explored the internal views of the interviewees and their personal experience of inter-organisational collaboration. It was also explorative, because little work on inter-organisational collaboration amongst PAOs in South Africa was found.

Although there were some expectations, based on the literature, as to what might be found, an inductive grounded theory approach was followed in the interview process. This was because, although inter-organisational collaboration is an established field, what 
might be found in the PAOs in South Africa was unknown. Grounded theory requires multiple stages of data collection and interpretation (Leedy and Ormrod 2001).

A follow up questionnaire, using a derived set of initial conclusions was used to confirm or reject the findings. This substantiates the outcomes presented here.

\section{Population and sampling}

Joffe and Newton (2008) categorise two groups of performing arts: upstream arts and downstream arts. For the purposes of this study, upstream arts were covered and the focus was limited to PAOs. These include theatre, dance, orchestra, opera, choir, musical theatre and any other live theatre. The classification of PAOs given in the 2008 creative industries report by the South African Department of Labour (Joffe and Newton 2008) was used in determining the range of entities to be included. These include commercial producers, theatres, festivals and independent companies (Joffe and Newton 2008). Another group, performing arts promoters, was included as they provided an outsider's perspective on inter-organisational collaboration amongst PAOs.

Theoretical (non-probability purposive) sampling was used (Saunders and Lewis 2012; Bryman 2012) to deliberately choose those individuals who would best help meet the research objectives. The researcher attempted to select a heterogeneous sample, with a good mix of strategic decision-makers from all types of PAOs. This was to ensure the sample would 'have sufficiently diverse characteristics' to ensure that any patterns uncovered would reflect a reality across PAOs (Saunders and Lewis 2012, p. 139). Thirteen interviews were conducted with strategic decision-makers, who represented the five diverse types of organisations. Fifteen PAO types are represented (see Table 1) even though 13 interviews were conducted because one of the respondents was affiliated with more than one

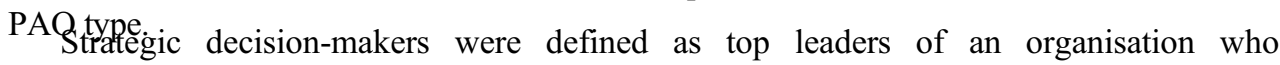
critically affect organisational health and survival (Eisenhardt and Zbaracki 1992). Directors, artistic directors, general managers and senior executive staff are typical examples of strategic decision-makers. Sullivan et al. (2011) argue that collaboration involves strategic decision-makers in organisations who are understood to have 'situated agency'. The study focused on interviewing strategic decision-makers as they have the power to take action, set precedents and make decisions on allocation of resources (Eisenhardt and Zbaracki 1992).

Table 1. Summary description of PAOs.

\begin{tabular}{|c|c|c|}
\hline PAO Type & No. & Description \\
\hline $\begin{array}{r}\text { Commercial } \\
\text { producers }\end{array}$ & 1 & $\begin{array}{l}\text { Producers who stage local and international shows to generate maximum } \\
\text { income for the promoters. }\end{array}$ \\
\hline Theatres & 4 & $\begin{array}{l}\text { 'Receiving houses', which act as venues for productions that have } \\
\text { varying amounts of public and private sector support that are able to } \\
\text { produce or commission work. }\end{array}$ \\
\hline Festivals & 2 & Provide a platform and funding for the production of new work. \\
\hline $\begin{array}{l}\text { Independent } \\
\text { companies }\end{array}$ & 6 & $\begin{array}{l}\text { Theatre, dance, orchestra, opera and choir companies that apply for } \\
\text { funding to the lottery, the National Arts Council, provincial funding } \\
\text { bodies and the private sector for support for their work. }\end{array}$ \\
\hline Promoters & 2 & $\begin{array}{l}\text { Performing arts media, unions and associations who support but do not } \\
\text { create art. }\end{array}$ \\
\hline
\end{tabular}


As indicated earlier, the PAOs ranged in staff sizes (including performers) from around a dozen at the low end and over 100 staff at the high end. They were professionally run, mostly not-for-profit organisations (but including some for-profit organisations) that were nonetheless under commercial pressure. They were all urban and all but two were based in Johannesburg. They were all working strategically and making progress in broadening the base of support to a younger audience as well as more multiracial audiences. They covered music, dance, orchestra, opera and theatre. Festivals also included visual, fine art, digital art and film.

This sample of organisations represents an important grouping, but because of its focus, findings may not be generalised across other PAO forms such as rural and small grassroots PAOs.

\section{Data-collection method}

The interviews were structured to be inductive, qualitative and exploratory in nature, because there was uncertainty as to how PAO strategic leaders would feel about interorganisational collaboration in general. An inductive approach allows themes to develop and the focus to change as data are gathered and analysed (Saunders and Lewis 2012). The interviews were semi-structured and explored feelings, experiences and opinions regarding the barriers to collaboration.

All interviews were conducted at the offices of the interviewee, apart from two: one who preferred to respond via email and another via Skype. The population was limited to Johannesburg.

The outline of the semi-structured questionnaire is detailed below in Table 2 .

\section{Data analysis}

The interviews were analysed using a combination of content, comparative and narrative analysis using a software package (Atlas.ti). Narrative analysis is a tool for identifying meaning in qualitative research, because it helps to put together "the "big picture" about experiences or events as the participants understand them' (Schutt 2011, p. 339). Quotes were coded and codes were aggregated into 'code families' or themes.

Table 2. The outline of the semi-structured questionnaire.

\begin{tabular}{ll}
\hline No. & \multicolumn{1}{c}{ The Key Questions } \\
\hline 1 & $\begin{array}{l}\text { Have you seen collaboration between PAOs? } \\
\text { Probe: In what ways? Ask for examples. }\end{array}$ \\
$2 \quad$ Where do you think collaborated between PAOs is lacking? \\
Probe: Everywhere / just one genre / stick to same partners, won't try new). \\
Why do you think PAOs are not collaborating more? \\
Probe: What specifically stops them? Ask for examples. Do you think this is the same for all \\
PAOs? What advice do you have for PAOs on collaboration? How can they do things \\
differently? \\
$\begin{array}{l}\text { Feelings on the performing arts industry (if time allows). How do you think the performing } \\
\text { arts industry is doing as a whole? What do you think the outlook for the performing arts is? }\end{array}$ \\
Can you say, in one word, what the industry is lacking? \\
Closing comments. Ask if respondent has anything else they would like to add.
\end{tabular}




\section{Reliability and validity}

Debate continues as to the value of the 'reliability' and 'validity' construct in qualitative research. But however they are operationalised, dependability and trustworthiness remain crucial (Golafshani 2003). How else can a researcher convince his or her audience that the findings are worthy of attention? The following actions were undertaken to strengthen the case being made.

Data analysis began before the data-collection phase was completed to identify and refine key concepts in an iterative process (Schutt 2011). Conversations amongst the researchers took place to allocate correct codings. This was done to strengthen the construct validity.

Once complete, a second phase of validation and consensus building took place through a questionnaire that was sent to respondents. This provided further insights into the questions posed. Five respondents answered the questionnaire and this either confirmed or cast doubt on the initial conclusions. This feedback was then incorporated into the findings presented here.

\section{Findings}

Whilst a number of broad interest areas and objectives were set at the beginning of the research, the focus here is on the barriers to collaboration amongst PAOs in South Africa. This was prompted by the need to stimulate demand for the performing arts. From the literature, three key relationships were identified as important: personal, organisational and contextual. The barriers to collaboration can be mapped onto these three domains, but an additional domain and associated barriers were also uncovered. We called this domain the personal-contextual domain. This finding and other details are described below.

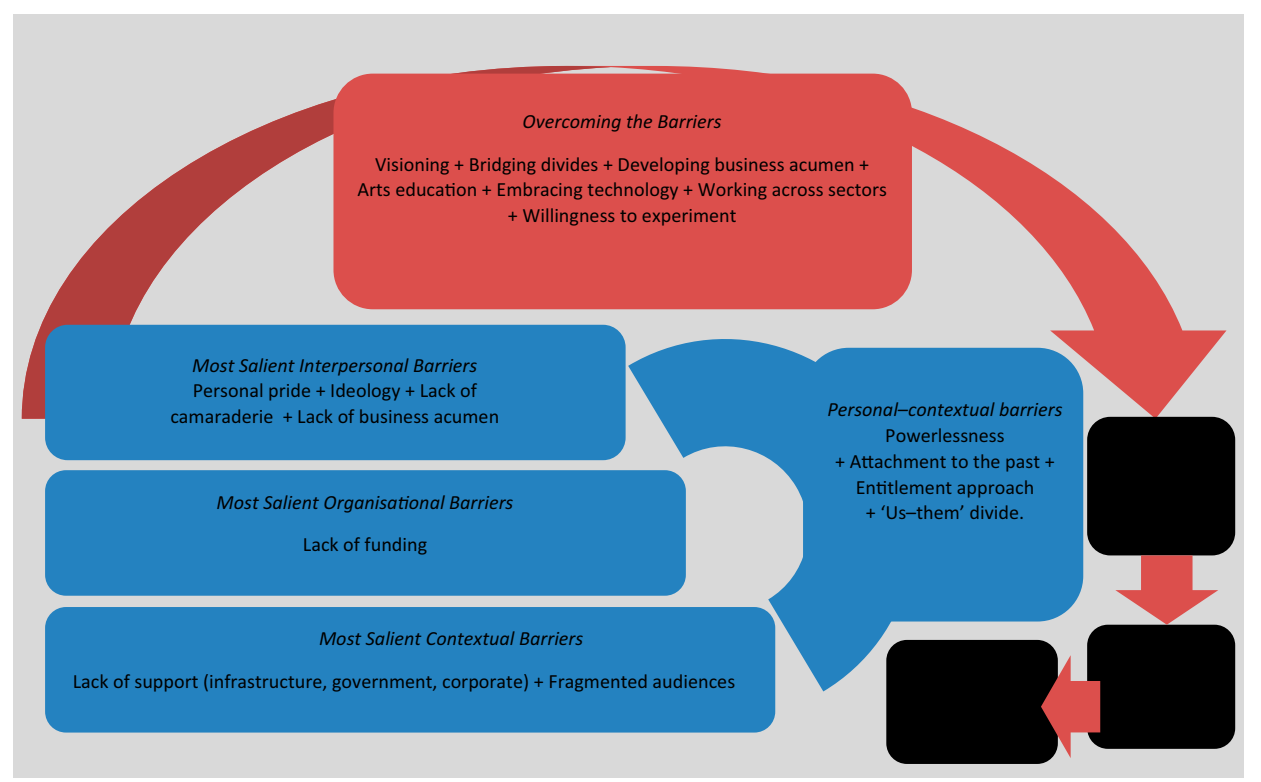

Figure 2. Barriers to inter-organisational collaboration and options for overcoming them. 


\title{
Barriers in the interpersonal domain
}

This theme emerged from a family of codes including barriers to collaboration such as personal pride, ideology, lack of camaraderie, a lack of business acumen and poor communication.

Personal pride: Personal pride, sometimes referred to as 'ego', was a particularly salient barrier for interviewees. The strategic decision-makers at the top sometimes have big personalities and this can lead to the holding of strong opinions. These characteristics are part of what makes them successful, but collaboration requires compromise which will inevitably lead to conflict.

Examples of statements pointing to personal barriers include:

\begin{abstract}
Believe you me, the clash of egos happens all over the world, not just in South Africa. Collaboration by its very name means you have to compromise, you have to meet each other halfway and you have to get beyond egos.

Each theatre thinks they know what they are doing. We don't like to be told what to do; we know what we are doing.

I can say I am very egotistic too and I also don't like anyone coming here and telling me how to run my company.
\end{abstract}

The majority of respondents recognised these characteristics in themselves and were able to admit they were themselves a barrier to collaboration.

Ideology: Many PAOs experienced clashes in ideologies. This is highlighted as a barrier by Ostrower (2003). People have differing management styles and operating approaches (Berger et al. 2004). Strong personalities hold strong opinions and each arts practitioner will have his or her own vision of what type of company they want to be, what types of shows they want to do and what defines their success. Ostrower (2003) disagrees with the diagnosis that strong personalities are a fundamental barrier. PAOs end up blaming the other's management styles or operating approaches for failure, when in fact it was an inadequate understanding of the project's requirements or a lack of expertise that led to failure. In this regard, the interviews indicated that a lack of business acumen is a barrier. This was further supported by the questionnaire responses.

Lack of camaraderie: Lack of camaraderie is closely aligned with what the literature says on trust. According to Das and Teng (2000), opportunism, whereby one partner tries to cheat the other so as to maximise its own profitability, is the greatest barrier to collaboration. There is a fear amongst PAOs that others may benefit at their expense. Within the literature of the interpersonal domain, trust matters. Trust in collaborations helps to create 'relational capital' (Parkhe 1993, Dyer and Singh 1998, in Graf and Rothlauf 2011). Trust is difficult to achieve in dynamic networks because of their brief lifespan (McCarthy 2006). Trust is built up gradually, through long-term commitment, further increasing collaborative effectiveness (Percy 2010). Tsasis (2009) found that partner organisations that did not have a clear and consistent direction were experienced as untrustworthy. This is because a relationship that had started as complementary could change into becoming competitive. Trust is reinforced by the importance of personal relationships and friendships across the collaborative domain (Tsasis 2009, Ospina and Foldy 2010).

Lack of business acumen: The second-phase questionnaire added another barrier to inter-organisational collaboration, namely, a lack of business acumen. This is seen as part 
of the interpersonal domain, because it manifests itself in the issues of trust building and ego clashes.

\section{Barriers in the organisational domain}

This theme emerged from pulling together codes on barriers such as lack of funding, fear of competition, organisational policies, scheduling difficulties associated with differing PAO priorities, programme content, artistic uniqueness, belief in the inability of partners to add value, and the absence of collective planning.

The most salient barrier in this area was the lack of funding, associated with a survivalist approach and associated fear of competition.

Lack of funding: The lack of funding was a prominent issue among interviewees. Respondents expressed that they felt they were given so little money that there is just not enough of it left over to collaborate. Or that the constant pursuit of the next show (to ensure survival) meant there was little long-term planning. Examples of statements pointing to a lack of funding include:

None of us have enough money in this country to say let's devote the next year to working on collaboration, let's spend that time with the people we identify and would like to collaborate with.... I do also think it's a lack of time...in the end lack of time comes down to a lack of money, because if we had more resources, if I didn't have to do three jobs for this theatre at the same time to keep my job, I would be able to spend more time nurturing those relationships.

But [collaboration] is a very hard thing to do because currently we are all fighting for the same funding and it's overcoming that initial fear.

There was also concern around people losing their jobs with statements such as:

But somebody will lose their job! If each company has their own ballet mistress, marketing person, rehearsal person then one will have to go to save costs. Even dancers will lose their jobs.

Although this concern was specifically associated with dancers losing their jobs, there was broad concern around job losses.

I think essentially people are going to lose their jobs.

Another reason why the lack of funding was seen as a barrier to collaboration was because PAOs believed that collaboration meant sharing their funding as opposed to pooling their funding or using the funds to co-create a production which would ultimately lead to greater ticket sales. This finding contradicts Kotler and Scheff's ( 1997) experience that the financial upside to collaboration is either cost savings or increased income due to increased ticket sales.

\section{Barriers in the contextual domain}

This theme emerged from a family of codes including lack of support (from government and the corporate sector as well as insufficient infrastructure in and around artistic hubs), 
a fragmented audience, pressures to 'transform' to a more representative workforce and funding application processes that do not support collaboration.

The most significant codes in this domain were the lack of support and a fragmented audience.

Lack of support: PAOs felt that those who did provide funding did so without really understanding the challenges faced by PAOs:

But even then when we were sponsored by [the company], they did nothing to publicise it even in-house.

A number of respondents mentioned a lack of city infrastructure as a constraint to development of the sector and a barrier to collaboration. PAOs also experienced a lack of support from the private sector. Many felt that businesses do not think of the arts as a business and do not understand the challenges faced by PAOs. Often businesses will provide funding in the form of a hand-out with no follow-through support such as marketing, publicity or involvement of commercially-minded administrators. This discourages PAOs from working with private business. This is in line with Weinstein and Cook (2011), who see misaligned goals and unequal levels of commitment to the collaboration as barriers to collaboration.

The funding application process in South Africa also seems to limit collaboration among PAOs as the process is arduous, stringent and often does not result in the necessary funds being acquired.

The other challenge is that you look at funding bodies that give money to all of us...they require that you only spend $15 \%$ of the grant that they give you on administration and on the salaries of the people that you hired for that particular project. The rest is on the project...so if you have R1 million to do a production, you only have R150,000 to pay the people that are going to make sure the production goes on.

These statements suggest that government arts policy has become more of a barrier to collaboration than an enabler.

Fragmented audience: Respondents also made comments that hinted at the divided nature of South African audiences:

They tried to produce South African black productions, the Soweto Story, and they failed and even a lot of the productions that come from abroad, the sort of Broadway-type things that have been losing money. Take Dreamgirls at the Monte Casino, you could argue that that is a developmental project because they cast a predominantly black South African cast for a play to take to Monte Casino, which we know has a predominately white audience. And clearly the white audience who generally go there are not ready for that even though it won awards and was a fantastic show.

It's all so separated...the Afrikaans population that wants to see an Afrikaans musical tends to go to the State Theatre. Joburg does not get the Pretoria audience and Pretoria does not get the Joburg audience. So they kind of categorise and say Afrikaans productions do not belong in [this] theatre.

Comments reflected that the current and potential South African audience do not like to take risks on unknown shows, prefer light-hearted entertaining shows to heavy storybased shows, lack arts education and appreciation, lack the habit of theatre-going, typecast theatres as being 'Afrikaans', 'black' or 'white', and demonstrate inflexibility by 
only patronising theatres that support their race, culture and language. In addition, some PAOs felt that their audience judges them very strongly on their most recent performances alone instead of looking at the quality of their performances over a number of years. This in turn leads PAOs to form quite harsh opinions of their audience base and this influences their appetite for collaboration, as they have become nervous to try new things, push boundaries and diverge from their conventional artistic code. They feel compelled to work within the confines of their target market's preferences, as anything radically different results in poor ticket sales.

Further analysis revealed inconsistencies regarding what PAOs felt the South African audience wants to see, especially the emerging black middle class. The developmental PAOs felt that this social caste wants to see stories that reflect their own lives. The commercial PAOs felt that the South African audience in general and the new black middle class in particular just want to be entertained and see the shows that they hear about overseas.

The diversifying of audiences is also important for the South African government:

I think that in general that mandate towards diversity is a very strong mandate in all South African theatres, nobody wants only a white audience everyone is trying to get a racially diverse audience.

Many theatres continue to strive for a broader 'black' audience by collaborating with black practitioners, but as indicated here some respondents felt that getting the mix of audience was difficult.

\section{Barriers in the personal-contextual domain}

An unexpected finding from this research was a range of barriers to collaboration that could not easily fit into the original three categories. These barriers emerged from the context, but are more psychosocial in nature. The cluster of codes described a set of mindsets (rather than behaviours) that are entwined within the South African context. These codes included powerlessness, an attachment to the past, an entitlement mentality and an 'us-them' divide. Because of the interplay of both context and mindset, this theme is described as personal-contextual barriers. The emergence of this theme required an iterative reading of the data, a deeper sense of what may be happening and constraining the sector. This is offered more tentatively, but hopefully initiates further inquiry into how to collaborate.

Powerlessness: For example, with regards to powerlessness, respondents spoke of political obstacles that further eroded their ability not only to collaborate but to continue to operate. In South Africa government arts funding has shifted to more of a grassroots orientation. The impact of this policy move on PAOs shows, quite obviously, that their voice in this decision was limited or absent. This indicates a lack of success in the initiatives by the industry to engage government in the formation of an arts policy that serves the needs of both the organisations and society.

There was a sense that the fate of the arts was dependent, not on the collective efforts of the industry, but on the will of the government. PAOs need to become more proactive in the development of arts policy, especially in the face of competing political agendas (Galli 2011). This finding is not unique to South Africa. Galli (2011) speaks about political agendas that influence decisions either to reduce or reallocate state expenditure 
on the arts. PAOs experienced their relationship with government and the operating environment as deeply disempowering. Whilst Cook and Hunsaker (2001) see organisations operating within certain constraints, there are alternative views that see the potential for situated agency (Sullivan et al. 2011). These boundaries are not fixed and continue to shift over time, meaning they can be influenced by the various constituents within them (Senge 1990a). Different constituents in a democratic system can work together to achieve a common goal (Bryson et al. 2006).

Attachment to the past: There is an attachment to the past. PAOs fear the risk that comes with trying new things. Used to operating in a certain way, they sometimes expressed fear at any new suggestions, particularly around money and competition. Many PAOs made reference to policies and ways of thinking that have, by their very steadfast nature, become barriers to collaboration. As some respondents said:

...that orchestra has been in existence for a long time and this company has been in existence for a very long time but they never had collaborations before.

The above comment indicates a perspective associated with keeping things as they are.

I think that's the thing that stops [collaboration] from happening...fear of either being outshone or fear of losing the grasp of what you know...

Entitlement mentality: The issue of entitlement emerged from some of the interviewees. This manifested in the ways in which the sector felt it deserved funding from corporations and the government, because the arts are a social good or because previously disadvantaged black artists or a black audience are involved:

We are a necessary subsidy institution. Don't let anybody tell you otherwise. If anybody thinks we can ever become self-sufficient, they are lying through their teeth!"

"I don't think there is a single country, even the most developed Western country, that doesn't subsidise and support its arts. If government supports health, they support education, they support the development of roads, then support for the development of arts and culture is just as important.

History and circumstances dictate that the performing arts should be subsidised. The industry battles to contain costs and for most companies ticket sales simply do not cover expenditure (Kirchner et al. 2007). While this reality is appreciated, there is a sense from the interviews that some PAOs may not be as aggressive in looking for ways to market themselves, because they felt they were deserving of external support. PAOs are deserving of support; the question is what to do if it does not come.

'Us-them' divide: There is an expressed divide between the commercially minded theatre practitioners who strive for profit and thus need to produce shows of novelty and entertainment value versus the developmental practitioners who use the arts as a means of telling a story, preserving culture and history. There is a racial element to this, with the former largely producing shows that have historically often had a majority white audience and the latter producing shows that have historically had a black audience. This divide, whilst not by any means representing the whole reality, also exists in the minds of some of the interviewees. Despite concerted efforts on the part of PAO leaders to lead across 
the divide, it potentially makes it much more difficult, for example, to build a shared vision, which emerged as crucial in the interviews and in the questionnaire responses.

South Africa's turbulent political history has, despite some work to transform the situation, not been erased from the minds and hearts of many South Africans. And PAOs are not immune to these challenges. In the research there was still some concern from some black theatre practitioners about whether and how to take their work to white practitioners.

Before the advent of democracy, music, theatre and dance were used to generate international support for the struggle against apartheid (Gilbert 2007). The purpose of art was not only to portray the plight of the suffering, but also to 'educate, awaken political consciousness and galvanize people into action' which meant that 'truly revolutionary art' was not the type that simply provided entertainment for the masses (Gilbert 2007, p. 436). It could be that this ideology and perception of art as an instrument of political expression as opposed to a form of entertainment is what keeps both audiences and theatre practitioners divided. Perhaps there are two distinct and mutually exclusive markets and those PAOs whose ideology is driven by 'the passion of the times' will never see eye to eye with those whose ideology is driven by entertainment value. The gap between these two mindsets does constrain collaboration and the potential for nation building. The government's unintended role in the creation and fortification of the 'us-them' divide between commercial and developmental PAOs needs to be addressed if collaboration and ultimately social inclusion is to improve. As one more commercially minded director indicated:

\footnotetext{
I think in this country at the moment, the arts are bogged down by these wide differences between developmental and experimental theatre on one side and what they label commercial theatre on the other.... And for theatre to really develop in this country I believe that gap needs to be narrowed. The people that create experimental and developmental theatre have got to do it with more of a commercial viewpoint and we running so-called commercial theatres have got to be more open to presenting developmental theatre to our audience.
}

The 'us-them' barrier has been around for most of the twentieth century across the world with the main difference being non-profit PAOs typically producing high art, while forprofit PAOs engage in mass cultural entertainment (McCarthy et al. 2001). In addition, non-profit or developmental PAOs strive to fulfil a social purpose and focus on artistic excellence, while commercial PAOs are more focused on their bottom line and as such need to produce or select shows that provide novelty and entertainment (Cherbo 1998). Therefore the divide and lack of collaboration between these two types of PAOs is understandable. However, there are historical synergies between commercial and developmental PAOs in American theatre whereby non-profit theatres provided a rudimentary research and development laboratory for shows that went on to become commercial successes on Broadway (Cherbo 1998). This is evident in some areas of South Africa but is not as widespread.

\section{Overcoming the barriers to collaboration}

All of the PAOs interviewed had collaborated in some form and had a good idea of what worked and what did not work. They had a mix of positive and negative experiences. 
Based on what did not work and on their extensive industry experience, the researchers were able to develop their understanding of the barriers outlined above.

The literature on collaboration offers some insights into how to overcome these barriers. Where this is substantiated by the views of respondents, this is indicated. All four of the barrier domains that emerged are covered. For example, 'visioning' is a personal leadership capacity but could also manifest at a contextual level.

Visioning: Vision is mentioned across the literature as an important enabler of collaboration (Tsasis 2009). Divides in the context of an industry operate as a constraint on vision building. PAOs sensed a change is in order, a change that only the PAOs themselves can effect. This vision can only be accomplished through aspirational leadership and collective action from all PAOs. PAOs that disregard the importance of a shared vision for the industry as a whole will continue to operate in the same way, moving from one crisis to the next, denying the role that each PAO plays in the system that is the performing arts industry.

The literature on collaboration proposes that PAOs that wish to effect change and think differently about the industry need to take time, regularly, to look beyond their immediate pressures and artistic ideals and work together strategically on a shared vision for the future.

...we all fight for our little thing...like everything, there is always competition.... So no one is looking at the bigger picture and the bigger picture is the hardest to solve.

Senge (1990b) advises that visioning is an on-going process that needs to evolve as the predominant vision of the future evolves. It is acceptable for each PAO to have its own artistic vision, but the long-term industry vision should be an underlying force that drives individual visions so as to achieve industry progress. One respondent spoke of this as 'solving the bigger picture'. Visioning can be threatening to an industry that has experience of apartheid oppression and is only beginning to find its freedom. This is a potential avenue for future inquiry. The bigger problem is that PAOs are competing against other entertainment industries, their audiences are generally older and not as diverse as ideally hoped for. The bigger vision that is needed in this context is the vision for a younger more diverse audience that is educated in the arts and is active in attending arts performances.

Bridging divides: Overcoming the barriers would require integrative public leadership' which brings together diverse institutions (government, business, civil society, nonprofit organisations, cultural institutions and the media) in order to solve complex social problems and achieve the common good (Crosby and Bryson 2005, 2010, Bryson et al. 2006). Ospina and Foldy (2010) identify five practices of organisations successful at 'securing the connectedness needed to bridge divides'. These practices include: prompting cognitive shifts, naming and shaping identity, engaging in dialogue about difference, creating equitable governance mechanisms, and weaving multiple worlds together through interpersonal friendships. Respondents mentioned good relationships as a key enabler of collaboration.

Ospina and Foldy's ideas of 'prompting cognitive shifts' and 'naming and shaping identity' are particularly important for bridging divides. Prompting cognitive shifts is the work of creating a sense of shared interest. This is crucial to the process of building bridges and alliances, because organisations must frame their issue in ways that resonate with the needs of others (Snow et al. 2004). An example of this would be gay rights 
activists positioning their work as championing the rights of all marginalised people and human freedom in general. This broader frame orients multiple actors to work on the issues together.

In a similar way, naming and shaping identity can be a powerful connector. Identity has been shown to be important in leadership research. Leaders prompt others to identify with them and their organisation (Shamir et al. 1993, Ospina and Foldy 2010). Do PAOs define themselves as independent artistic entities or do they define themselves as potential partners, for example?

Developing business acumen: A lack of formal metrics or general research on collaboration seems to be a problem in the performing arts industry. It was often unclear to respondents whether their previous collaborations had increased ticket sales. If collaboration was approached and measured more scientifically, perhaps there would be more of it. Boorsma and Chiaravalloti (2010) recommend a performance management model based on Kaplan and Norton's Balanced Scorecard to inform the evaluation of PAOs' performance.

One idea from the business literature is for PAOs to see the potential for "coopetition'. Co-opetition refers to the actions of working together to build an industry, but also competing for differing parts of the market. Leaders who understand co-opetition may, for example, collaborate when it comes to creating a pie and compete when it comes to dividing it up; therefore they have to compete and collaborate at the same time, which creates a more dynamic relationship (Brandenburger and Nalebuff 1996). This suggests mutual interdependence in the interest of all those involved to maintain and generate business and sell more (Hearn et al. 2007).

Co-opetition is currently practised in the automotive industry, where car manufacturers who compete globally may share a manufacturing plant. This reduces the costs of setting up independent plants. The companies may go so far as to share some parts to further reduce costs. This is currently done by Renault and Nissan, for example. It is also practised by business schools in South Africa, who compete for students in the MBA programme, but who may come together to engage with government around shared concerns. It is also practised by tech companies such as Google, which developed an operating system (Android) that other companies that compete in other areas can use.

Embrace technology: The increase in consumption of recorded and digitised art at the expense of live art and the effects of digital technology and the internet on the performing arts industry have yet to be comprehensively evaluated and documented (McCarthy et al. 2001). This does not mean PAOs should turn a blind eye to technology and the changing cultural landscape. 'Technological innovation' was one of the ways to encourage collaboration that was mentioned frequently in the literature but seldom in the study. Most PAOs were unsure when asked whether theatre is dying because technology has changed the way people entertain themselves. Forward-thinking PAOs should consider how using technology and other mainstream media collaborations may be able to grow demand for their products. Various resources are already available to PAOs to help them better understand how they can reconnect with the distant youth market using social media, video and other web and mobile-based applications (NAMP NPower 2006, Carr and Paul 2011, Galli 2011). In addition, it is not all doom and gloom for PAOs willing to embrace technology, as participation through electronic media was shown to affect live participation positively (Galli 2011).

Work across sectors: The literature on cross-sector collaboration supports the view that sectors (and the organisations within them) need to work together to solve complex 
social problems and produce economic and developmental gains (Crosby and Bryson 2010). Development in a creative cluster's infrastructure, transport system, services and amenities is a examples of how government and local municipalities can benefit the community by supporting the creative sectors (Hearn et al. 2007). The area of Newtown in Johannesburg is a good example of where government, the local community, the infrastructure and transport sectors, and the arts sector have collaborated to turn a previously unproductive area into a cultural hub. A more recent development in Johannesburg, Maboneng, has been led by the private sector, which then reached out to government to develop the areas of the city. Because of this collaboration across sectors, the area is developing as an important arts hub in Johannesburg.

Willingness to experiment: Heifetz (1994) proposes that the nature of work for change involves adaptive and technical challenges. Queen (2011) explored some of these dynamics specifically in the collaborative context of private-public partnerships. Change requires learning at the level of values, culture and industry norms. Leaders in PAOs must be willing to experiment carefully and intelligently with new ways of doing things and stimulate collective learning. This is a painful but essential process. Some PAOs showed evidence of this kind of thinking:

We are going to collaborate because we can pool our audiences, we are going to collaborate because it is bringing in a completely new and creative way of thinking into an environment that has become stale and tired, we are going to collaborate because it means we can shift where we see ourselves in five years.

\section{Conclusion}

The performing arts sector in South Africa faces significant ongoing financial pressures. These are unlikely to subside and are partly the result of the increasing competition from a range of entertainment options. New solutions are needed. One option is to collaborate in strengthening primary demand and increasing the size of the pie. PAO strategic leaders face a range of barriers to collaboration that need to be overcome. The literature on interorganisational leadership offers some insights on this problem.

\section{Summary of findings on barriers to inter-organisational collaboration}

Empirical themes were identified through in-depth qualitative research supported by a questionnaire with five key respondents. Three domains were identified in the literature: interpersonal, organisational and contextual. PAOs identified the most salient barriers to inter-organisational collaboration associated with each of these themes.

1. Personal barriers included personal pride and its constraint on working together, and differing ideological ideas about the role of PAOs. They also included a lack of camaraderie in the industry and a lack of business acumen.

2. Organisational barriers (most salient) included lack of funding and an associated survivalist approach.

3. Contextual barriers occurred through lack of support from government and business, and the challenge of fragmented audiences. 
The identification of these specific barriers makes clear what PAO strategic leaders face as they try to collaborate further. One interesting finding was the emergence of themes that at first reading appear contextual, but on further exploration reveal a strong mindset or psychosocial dimension. This theme was then called personal-contextual.

4. Personal-contextual barriers included a sense of powerlessness, an attachment to the past, an entitlement mentality, and an 'us-them' divide.

\section{Implications for practitioners and PAO strategic decision-makers}

Inter-organisational collaboration is not a silver bullet and can create problems (Connelly 2007). But there are advantages to collaboration. Identifying barriers is only the first step. The next question becomes how to overcome these barriers. Every one of the PAOs had collaborated in some form and had a good idea of what worked and what did not work.

Based on what did not work and on their extensive industry experience, the respondents gave numerous suggestions on what to do differently or how to make collaboration more effective. These were extended with reference to the literature.

Suggestions included the need for: visioning, bridging divides, developing business acumen, arts education, embracing technology, working across sectors and maintaining a willingness to experiment.

\section{Additional questions for research}

In terms of theory building, this study builds on the growing current literature on 'inter' leadership and inter-organisational collaboration (Huxham and Vangen 2000, Crosby and Bryson 2005, Guo and Acar 2005, Connelly 2007, Morse 2010, Ospina and Foldy 2010, Müller-Seitz 2012). This study makes a contribution to the literature that is part of a broader relational and 'shared-power' turn in leadership studies, where collective action is increasingly required. The great importance of contextual barriers confirms the call of Müller-Seitz (2012) for an increased 'field-level' analysis.

For practitioners, the problem of inter-organisational collaboration in the performing arts was identified. It appears as if inter-organisational collaboration (as a means of stimulating primary demand) is constrained when the financial pressures on a sector are so great as to push organisations into a fight or flight response and survivalist mindset of 'every man for himself'. This finding should be explored further.

The personal-contextual barriers need to be engaged and overcome if the performing arts industry is to thrive. They emerge uniquely from the context of post-apartheid transitional democracy in South Africa. A specific personal effort, started by many already, needs to be made by all strategic decision-makers across the entire performing arts industry to bridge the personal-contextual barriers that derive from our past but continue to be alive in the present.

\section{References}

BASA, 2009. The South African Ballet Theatre (SABT) - URGENT CALL FOR FUNDING. Available from: http://www.basa.co.za/pages/news-article/the_south_african_ballet_theatre_sabt_ urgent_call_for_funding/[Accessed 4 April 2012]. 
Berger, I.E., Cunningham, P.H., and Drumwright, M.E., 2004. Social alliances: company/nonprofit collaboration. California Management Review, 47 (1), 58-90. doi:10.2307/41166287.

Boorsma, M., and Chiaravalloti, F., 2010. Arts marketing performance: an artistic-mission-led approach to evaluation. The Journal of Arts Management, Law, and Society, 40, 297-317. doi:10.1080/10632921.2010.525067.

Brandenburger, A.M., and Nalebuff, B.J., 1996. Co-opetition. New York: Doubleday.

Bryman, A., 2012. Social research methods. 4th ed. New York: Oxford University Press.

Bryson, J.M., Crosby, B.C., and Middleton-Stone, M., 2006. The design and implementation of cross-sector collaborations: propositions from the literature. Public Administration Review, 66 (1), 44-55. doi:10.1111/j.1540-6210.2006.00665.x.

Carr, E., and Paul, M., 2011. Breaking down the fifth wall: rethinking arts marketing for the 21st century. New York: Patron.

Cherbo, J.M., 1998. Creative synergy: commercial and nonprofit live theatre in America. Occasional Paper Number Three. Columbus, OH: Ohio State University.

Child, J. 2003. Learning through strategic alliances. In: A. Dierkes, Berthoin Antal, J. Child and I. Nonaka, eds. Handbook of organizational leadership and knowledge. New York: Oxford University Press, 657-680.

Colbert, F., 2009. Beyond branding: contemporary marketing challenges for arts organizations. International Journal of Arts Management, 12 (1), 14-20.

Connelly, D., 2007. Leadership in the collaborative interorganizational domain. International Journal of Public Administration, 30, 1231-1262. doi:10.1080/01900690701230150.

Cook, C.W., and Hunsaker, P.L., 2001. Management and organizational behavior. 3rd ed. Boston, MA: McGraw-Hill Irwin.

Crosby, B.C., and Bryson, J., 2005. A leadership framework for cross-sector collaboration. Public Management Review, 7 (2), 177-201. doi:10.1080/14719030500090519.

Crosby, B.C., and Bryson, J., 2010. Integrative leadership and the creation and maintenance of cross-sector collaborations. The Leadership Quarterly, 21 (2), 211-230. doi:10.1016/j.leaqua. 2010.01.003.

d'Astous, A., Colbert, F., and Fournier, M., 2007. An experimental investigation of the use of brand extension and co-branding strategies in the arts. Journal of Services Marketing, 21 (4), 231-240. doi:10.1108/08876040710758531.

Das, T.K., and Teng, B.S., 2000. Instabilities of strategic alliances: an internal tensions perspective. Organization Science, 11 (1), 77-101. doi:10.1287/orsc.11.1.77.12570.

Dyer, J.H., and Singh, H., 1998. The relational view: Cooperative strategy and sources of interorganizational competitive advantage. Academy of Management Review, 23 (4), 660-679.

Eisenhardt, K.M., and Zbaracki, M.J., 1992. Strategic decision making. Strategic Management Journal, 13 (special issue), 17-37. doi:10.1002/smj.4250130904.

Galli, J.D., 2011. Organizational management in the non-profit performing arts: exploring new models of structure, management, and leadership. Master of Science in Arts Management, University of Oregon, OR.

Gilbert, S., 2007. Singing against apartheid: ANC cultural groups and the international antiapartheid struggle. Journal of Southern African Studies, 33 (2), 421-441. doi:10.1080/ 03057070701292848 .

Golafshani, N., 2003. Understanding reliability and validity in qualitative research. The Qualitative Report, 8 (4), 597-607. Available from: http://www.nova.edu/ssss/QR/QR8-4/golafshani.pdf. [Accessed 29 May 2013].

Graf, N., and Rothlauf, F., 2011. The why and how of firm-NGO collaborations. Department of Information Systems and Business Administration. Johannes Gutenberg-University Mainz, Germany. Available from: http://wi.bwl.uni-mainz.de. [Accessed 6 May 2012].

Guo, C., and Acar, M., 2005. Understanding collaboration among nonprofit organizations: combining resource dependency, institutional, and network perspectives. Nonprofit and Voluntary Sector Quarterly, 34 (3), 340-361. doi:10.1177/0899764005275411.

Hardy, C., Phillips, N., and Lawrence, T.B., 2003. Resources, knowledge and influence: the organizational effects of interorganizational collaboration. Journal of Management Studies, 40 (2), 321-347. doi:10.1111/1467-6486.00342. 
Hearn, G.N., Roodhouse, S.C., and Blakey, J.M., 2007. From value chain to value creating ecology: implications for creative industries development policy. International Journal of Cultural Policy, 13 (4), 419-436. doi:10.1080/10286630701683367.

Heifetz, R., 1994. Leadership without easy answers. Cambridge, MA: Harvard University Press.

Hogg, M.A., Van Knippenberg, D., and Rast, D.E., 2012. Intergroup leadership in organisations: leading across group and organisational boundaries. Academy of Management Review, 37 (2), 232-255. doi:10.5465/amr.2010.0221.

Hume, M., Sullivan Mort, G., and Winzar, H., 2007. Exploring repurchase intention in a performing arts context: who comes? and why do they come back? International Journal of Nonprofit and Voluntary Sector Marketing, 12, 135-148. doi:10.1002/nvsm.284.

Huxham, C., and Vangen, S., 2000. Leadership in the shaping and implementation of collaboration agendas: how things happen in a (not quite) joined-up world. The Academy of Management Journal, 43 (6), 1159-1175. doi:10.2307/1556343.

Jaskyte, K., and Lee, M., 2006. Interorganizational relationships: a source of innovation in nonprofit organizations? Administration in Social Work, 30 (3), 43-54. doi:10.1300/J147 v30n03 04.

Joffe, A., and Newton, M., 2008. Creative industries in South Africa. Sector studies: Department of Labour, South Africa.

Kang, D.S., 2010. Understanding of consumption behaviors in art and cultural sectors for developing successful communication plans. Journal of Targeting, Measurement and Analysis for Marketing, 18 (3/4), 263-279. doi:10.1057/jt.2010.13.

Kirchner, T.A., Markowski, E.P., and Ford, J.B., 2007. Relationships among levels of government support, marketing activities, and financial health of nonprofit performing arts organizations. International Journal of Nonprofit and Voluntary Sector Marketing, 12 (2), 95-116.

Kotler, P., and Scheff, J., 1997. Standing room only: strategies for marketing the performing arts. Boston, MA: Harvard Business School Press.

Kushner, R.J., 2003. Understanding the links between performing artists and audiences. Journal of Arts Management, Law, and Society, 33 (2), 114-126. doi:10.1080/10632920309596570.

Leedy, P., and Ormrod, J.E., 2001. Practical research: planning and design. Upper Saddle River, NJ: Prentice-Hall.

McCarthy, B., 2006. Building and sustaining trust in networks: lessons from the performing arts. Irish Marketing Review, 8 (1-2), 47-57.

McCarthy, K., Brooks, A., Lowell, J., and Zakaras, L., 2001. The performing arts in a new era. Santa Monica, CA: RAND.

Morse, R., 2010. Integrative public leadership: catalyzing collaboration to create public value. The Leadership Quarterly, 21 (2), 231-245. doi:10.1016/j.leaqua.2010.01.004.

Müller-Seitz, G., 2012. Leadership in interorganizational networks: a literature review and suggestions for future research. International Journal of Management Reviews, 14 (1), 428-443. doi:10.1111/j.1468-2370.2011.00324.x.

NAMP NPower, 2006. NPower's technology guide for nonprofit leaders: a mission support tool for arts and culture. Available from: www.npower.org/files/page/techguide_arts.pdf [Accessed 26 October 2012].

Ospina, S., and Foldy, E., 2010. Building bridges from the margins: the work of leadership in social change organizations. Leadership Quarterly, 21 (2), 292-307. doi:10.1016/j.leaqua.2010.01.008.

Ostrower, F., 2003. Cultural collaborations: building partnerships for arts participation: community partnerships for cultural participation (CPCP). Washington, DC: Urban Institute.

Parkhe, A., 1993. Strategic alliance structuring: A game theoretic and transaction cost examination of interfirm cooperation. Academy of Management Journal, 36 (4), 794-829.

Patel, M.E., 2010. The new growth path: the framework. Republic of South Africa. Available from: www.info.gov.za/speech/DynamicAction?pageid $=461$ andsid $=14787$ andtid $=24857$. [Accessed 8 March 2012].

Percy, S.W., 2010. Cooperation. Learning from BP's experience with NGOs. Washington, DC and London: RFF Press.

Queen, J.Y., 2011. The adaptive challenges of collaborative leaders in a public-private partnership. $\mathrm{PhD}$ Dissertation. College Park, MD: University of Maryland.

Ricco, M.E., 2009. 21st century inter-organizational collaboration success and dedicated alliance function. Phoenix, AZ: University of Phoenix. 
Saunders, M., and Lewis, P., 2012. Doing research in business and management: an essential guide to planning your project. Essex: Pearson.

Schutt, R.K., 2011. Investigating the social world: the process and practice of research. 7 th ed. London: SAGE.

Sedita, S.R., 2008. Interpersonal and inter-organizational networks in the performing arts: the case of project-based organizations in the live music industry. Industry and Innovation, 15 (5), 493-511. doi:10.1080/13662710802373833.

Senge, P.M., 1990a. The fifth discipline: the art and practice of the learning organisation. New York: Doubleday.

Senge, P.M., 1990b. The leader's new work: building learning organizations. Sloan Management Review, 32 (1), 7-23.

Shamir, B., House, R., and Arthur, M.B., 1993. The motivational effects of charismatic leadership: a self-concept based theory. Organization Science, 4 (4), 577-594. doi:10.1287/orsc.4.4.577.

Shapiro, D., Sheppard, B., and Cheraskin, L., 1992. Business on a handshake. Negotiation Journal, 8 (4), 365-377.

Snow, D.A., Soule, S.A., and Kriesi, H. 2004. Mapping the terrain. In: D.A. Snow, S.A. Soule and $\mathrm{H}$. Kriesi, eds. The Blackwell companion to social movements. Malden, MA: Blackwell Publishing, 3-16.

Sullivan, H., Williams, P., and Jeffares, S., 2011. Leadership for collaboration. Public Management Review, 14 (1), 41-66. doi:10.1080/14719037.2011.589617.

Thomas, S.R., Pervan, S.J., and Nuttall, P.J., 2009. Marketing orientation and arts organisations: the case for business sponsorship. Marketing Intelligence and Planning, 27 (6), 736-752. doi: $10.1108 / 02634500910988654$.

Tsasis, P., 2009. The social processes of interorganizational collaboration and conflict in non profit organizations. Nonprofit Management and Leadership, 20 (1): 5-21.

United Nations. 2008. Creative economy report. US Unit for South-South Cooperation.

Weinstein, L., and Cook, J., 2011. The benefits of collaboration between for-profit businesses and nonprofit arts- or culture-oriented organizations. SAM Advanced Management Journal, 76 (3), 4-9. 